\title{
Towards Post Covid-19 Economic Recovery and Adjustments in Ebonyi State: The Role of Government Appointees in Ebonyi State, Nigeria
}

\author{
Dr. J.K.J Okonkwo
}

\begin{abstract}
The study examined the impact of the novel disease called Covid-19 on the socio-economic life of the people of Ebonyi State, nay Nigeria and the world; and prescribed some measures aimed at alleviating the impact of the disease during and mostly after the pandemic. The major objective was to suggest means of economic recovery and adjustments after the pandemic. Citizens of Ebonyi State including political appointees, legislators, members of the judiciary, public servants, etc were personally interviewed. Online and offline libraries were visited. The study found that there exist a number of programmes and policies put in place by both the Ebonyi State and Nigeria governments which if properly managed and accessed are capable of leading to a fast economic recovery after the covid-19 pandemic.
\end{abstract}

Index Terms - Covid-19; Post Covid-19; Economic recovery, Economic Adjustments; Pandemic.

\section{INTRODUCTION}

When in December 2019, the corona virus disease otherwise known as Covid-19, broke out in Wuhan, China, little did we know that the novel pandemic will take the devastating dimension it has assumed. No one anticipated that it will take a global proportion - bringing the world to a flatline. By March, 2020, barely three months of the outbreak, virtually all human institutions and activities were affected. Throughout the world movements were restricted, local and international flights were stopped, schools and colleges were closed, sporting activities were put on hold, hotels and recreational institutions were not spared, social gatherings were prohibited In fact, phrases like lockdown, social distancing, hand washing, face/nose masks, stay safe, stay at home, inter-state movements, palliatives, etc became the order of the day. Families were forced to bond.

Nigeria got its first share of the pandemic on February 27, 2020, when an Italian citizen in Lagos tested positive to the disease. Ten days later, on March 9, 2020, a second case was reported in Ewokoro, Ogun State. It was then that Nigeria and Nigerians came to realize that the virus is not just a Whiteman's disease as many hitherto believed.

State governments, including Ebonyi stepped up efforts to ensure that the disease does not enter their states. Inter-state movements were stopped by both federal and state governments. Mention must be made here of the tireless and frantic efforts of His Excellency, Engr. Dave Umahi, the
Governor of Ebonyi State, to avert the disease entering into Ebonyi State. But his efforts were sabotaged by citizens who could not stay where they were, and some security agents. Thus, on April 26, 2020, Ebonyi State recorded its index case - "imported" by a 31 year old transporter from Ukawu, who conveys food items to and fro Ore in Ondo State.

As at January 11, 2021, about a year after, the pandemic has claimed over 1,948,152 deaths worldwide from 90,983,215 confirmed cases. In Nigeria, within the same period, 1,358 deaths from 80,030 confirmed cases have been reported by the Nigerian Centre for Disease Control (NCDC). And Ebonyi State has become one of the epic centres in the South East with 45 deaths from 1,147 confirmed cases, as at January 10, 2021.

Economically, socially and politically, the world has never been the same and may not likely be same again. Worse still, the pandemic is not in a hurry to go. Invariably, world economy has been devastated: many jobs have been lost, companies liquidated, small and medium enterprises gone extinct.

\section{OBJECTIVES OF THE STUDY}

The major objective of this study is to examine the alternatives available to the people of Ebonyi State, Nigeria, to overcome the visible effects of covid-19. Specific objectives include:

(a) To find out the effects of covid-19 on the citizenry

(b) To suggest possible measures that can assist in quick economic recovery and adjustment

(c) To ascertain government efforts towards covid-19 economic recovery and adjustments

(d)To suggest personal economic adjustment strategies to the people of Ebonyi State.

\section{METHODOLOGY}

The study is explorative in nature because it is conducted for a subsisting problem which has not received the attention of many scholars. It is also a field research with information coming from personal interviews and library research. A cross section of Ebonyi indigenes spanning across the 13 local governments - including politicians, public servants, farmers, etc were engaged in open discussion, while online and physical libraries were consulted. 


\section{FINDINGS}

A. Effects of Covid-19 on the Citizenry:

It is crystal clear that even before the pandemic, Nigerian economy was fragile. And with the emergence of the pandemic and drastic reduction in oil price, it became worse. The citizens - both the rich and the poor became affected. Beyond the loss of lives, Covid-19 shock alone is projected to push about 5 million more Nigerians into poverty from last year, according to the World Bank. Before the outbreak of the virus, the number of poor Nigerians, were expected to increase by 2 million, largely due to population growth, the number will increase now by 7 million with a poverty rate projected from 40.1 percent in 2019 to 42.5 percent in 2020 (World Bank, 2020). (The current international poverty line is $\$ 1.9$ a day. With a rate of $\# 388$ to one dollar, it means one is poor if he/she doesn't make \#388 a day). The same World Bank reported that over 40 percent of Nigerians employed in non-farm enterprises reported a loss of income between April and May, 2020.

Unfortunately, the future is not even bright. Trading Economics (2020) paints a dim future for the economy that may make recovery difficult. It shows the following economic indicators for Nigeria:

Table 1: Nigeria: Basic Economic Indicators

\begin{tabular}{|c|c|c|c|c|}
\hline & Actual & $\begin{array}{l}1^{\text {st }} \\
\text { Qtr.202 } \\
0\end{array}$ & $\begin{array}{l}2^{\text {nd }} \\
\text { Qtr.202 } \\
0\end{array}$ & $\begin{array}{l}3^{\text {rd }} \\
\text { Qtr.202 } \\
0\end{array}$ \\
\hline $\begin{array}{l}\text { GDP growth } \\
\text { rate }(\%)\end{array}$ & $4^{-14 .}$ & -15.5 & 2.6 & 3.4 \\
\hline $\begin{array}{l}\text { GDP annual } \\
\text { growth rate }(\%)\end{array}$ & 1.87 & 0.6 & 1.0 & -7 \\
\hline $\begin{array}{l}\text { Unemploym } \\
\text { ent rate }(\%)\end{array}$ & 10 & 31.5 & 31.9 & 31.5 \\
\hline $\begin{array}{l}\text { Inflation rate } \\
(\%)\end{array}$ & $56^{12 .}$ & 12.7 & 12.5 & 13.5 \\
\hline
\end{tabular}

Source: Trading Economics (2020). Nigeria Economic Forecasts $\quad-\quad 2020 \quad-\quad 2022 \quad$ Outlook. www.tradingeconomics.com.

In fact, according to the United Nations (UN), "the Covid -19 pandemic is far more than a health crisis. It is affecting societies and economies at their core...". And Blanke (2020) opines that "half of Africans face food insecurity, of which 50 percent are severely insecure, while the number of people who are hungry is likely to double in 2020." The economic damage already caused by the pandemic is enormous. According to the World Bank (2020), "the pandemic is expected to plunge most countries into recession from 2020, with the per capita income contracting in the largest fraction of countries globally since 1870". Furthermore, the household survey carried out by the National Bureau of Statistics in Nigeria, confirmed that over 40 percent of Nigerian households could be classified as poor. It predicted that the economy could shrink by anything from 4.40 percent to 8.91 percent as a result of the pandemic.

In summary therefore, some of the visible effects of the Covid-19 pandemic on the entire citizens include:

1. Loss of jobs

2. Loss of, or reduction in income
3. Reduction in household consumption

4. Sharp rise in unemployment rate

5. Zero investment and/or drastic reduction in production

6. Increase in crime, including incest and rape (occasioned by lockdown)

7. Increase in the prices of food stuff and other household items

8. Hunger, as a result of shortage of food

9. Decrease in demand and subsequent decrease in purchasing power

10. Increase in the loss lives as a result of neglect to other ravaging existing diseases and lack of access to drugs and health facilities.

B. The Role of Political Appointees in Post Covid-19 Economic Recovery and Adjustments in Ebonyi State:

There are two aspects of the roles expected to be played here: Economic recovery and economic adjustments. The adjustment aspects will come as recommendations for this paper.

From all that we have reviewed above, it is very clear that the road to economic recovery after Covid-19 surely won't be an easy one. Secondly, it is apt to state here that prayers, fasting and miracles per se, will do little or no good in this direction. This becomes imperative because many 02 Yigerian have resorted to praying, fasting and tithing as the only solution to socio-economic tribulations bedeviling them. The Holy Bible succinctly spells it out that "faith without work is dead" on arrival (James 2.26). Even the founders of the four major of religions in the world - Jesus, Mohammed, 7 Gautama and Moses for Christianity, Islam, Buddhism and Juldaism respectively - emphasized the need for hard work 2 and taking responsibility. It is pertinent to note that the greatest problem this country is facing, outside corruption, is 2.5 religion. Religion has set us back so badly that some eommentators have said that we got independence unprepared. Professor Abel Idowu Olayinka, the $12^{\text {th }}$ substantive Vice Chancellor of University of Ibadan has this to say about Nigeria and religion:

After independence, in order to build a great nation, each country went to work. But Nigeria, after independence, our people went to pray and fast. So while we were praying and fasting, Malaysia came here and took our palm seedlings and built a great factory of it. While we were praying, Singapore went into investment in technology. While we were praying, India went into massive industrialization. While we were praying, the UAE went into massive infrastructural development. While we were praying, binding and casting Lucifer, Japan went into technological development. While we were speaking in tongues, Denmark went into education of her citizens. While we were mounting big loud speakers in our places of worship, USA was mounting man on the moon. After our prayers, God, being a wise God decided to reward us according to our labour ....That is why today, Nigerian pastors are competing in building the biggest churches. That is why there are more prayer houses and worship places than hospitals and schools. That is why people do rush to prayer houses for medical and business solutions instead of hospitals. That is why we don't do business feasibility studies before 
jumping into it since we are going to back it up with prayers. And when it collapses, we blame devil... That is why faith in God replaces building pillars and when it collapses we blame it on Lucifer. That is why our pastors are making sure they plant church branches instead of schools on every street in Nigeria. That is why we always wait for God to do for us that which ability would have accomplished. That is why we want our teachers to labour on earth and go to heaven for their rewards. Nigeria is a prayer loving, God fearing nation. Religion has taken the place of technology, infrastructure, education, etc. when travelling, we ignore all the necessary road requirements, servicing of our vehicles and pray. And once we pray, we can put a half serviceable vehicle on the road and blame our step mothers or mother in laws if anything goes wrong....Remember, both the Holy Bible and Holy Quran, emphasized on hard work and good services while condemning indolence and laziness of any kind.

The role to play for a genuine Post Covid-19 economic recovery and adjustments is enormous and not what faith alone can solve. Political appointees are expected to play the following roles to help Ebonyi citizens conquer hunger, gain employment, enhance purchasing power, access health care, etc. now and after the pandemic:

1. Fiscal Stimulus: the political appointees are expected to mount pressure on the Ebonyi Sttate Government to:

(i) Reduce taxes and VAT

(ii) Provide incentives to small and medium enterprises (SMES) to revitalize ailing or dead businesses

(iii) Provide interest free loans to genuine farmers to boost food production

(iv) Stimulate local businesses

(v) Give honoraria as unemployment benefits

(vi) Ensure that there is employment retention in the stead of retrenchment

(vii) Give social assistance benefits and financial support to the less privilege in the state

2. Lunch an Endowment Fund: Political appointees are encouraged to lunch an

Economic Recovery Endowment Fund for the purpose of raising investment fund for intending and existing Ebonyi young entrepreneurs. Prominent Eboyians and non-Eboyians resident in Ebonyi State should be approached to make donations to the fund, from where youths in the state can be empowered to begin small business activity.

3. Agricultural, Small and Medium Enterprises Scheme: Ebonyi citizens should be enlightened and assisted to access the Central Bank of Nigeria, Agric, Small and Medium Enterprises Scheme (AGSMEIS) loan. The AGSMEIS is a current initiative of the CBN where Nigerians can access up to \#10 million loan, at 5\% interest per annum, without collateral. The AGSMEIS is a voluntary initiative of the Bankers' Committee approved at its $31^{\text {st }}$ meeting held on February 9, 2017. The Scheme requires all banks in Nigeria to set aside 5 percent of their profits after tax (PAT) annually. The scheme is to support the Federal Government's efforts and policy measures for the promotion of agric business, small and medium enterprises (SMEs) as vehicles for sustainable economic development and employment. Your role here therefore, is to enlighten individuals who own or intend to own agric businesses, small and medium enterprises on how to access the loan. Unfortunately, over 90 percent of the Ebonyi population is ignorant of the existence of this facility. For 2020/2021, areas covered include:

(i) Agric business

(ii) Education

(iii) Health

(iv) Services (Hospitality, restaurants, catering, barbing/hair salons, etc

(v) ICT

(vi) Manufacturing

(vii) Mining

(viii) Creative industry (fashion, design, crafts, etc)float an Entrepreneur Training

To this effect, politicians, can float an Entrepreneur Training Institute (EDI) or liaise with existing EDIs in the state. This is a major condition for accessing the loan, because interested applicants would have to apply for the loan via an EDI, which sends the applications to the Central Bank of Nigeria (CBN) for processing. The $\mathrm{CBN}$ in turn invites the applicants for an interview. Qualified candidates are then required to complete some forms and loans are granted. A maximum of \#10 million loan can be granted for a 7 year tenor and 18 months moratorium. Other requirements for the loan include:

(i) Evidence of registration of business by the Corporate Affairs Commission (CAC)

(ii) Evidence of tax payment

(iii) Letter of introduction, from either a pastor, local government chairman, village head, senior public servant, etc

(iv) $\mathrm{BVN}$

(v) Letter of guarantee

(vi) Certification by an EDI

(vii) Passport photo of the applicant and his guarantor

(viii) Valid ID

4. Youth Investment Fund: The Federal Executive Council (FEC) on Wednesday, July 22, 2020 approved a \#75 billion Youth Investment Fund. The Fund is created to support entrepreneurs between the ages of 18 and 35. According to Sunday Dare, the Minister of Youth and Sports Development, persons within the age bracket with genuine business ideas are advised to pitch the ideas in any of the 125 Micro Credit Banks across the country and qualified candidates will have access to the fund.

5. Farming: Political appointees should be encourage their constituents to engage in vigorous farming to boost food production. Just recently too, the Governor of Ebonyi State directed that all aspiring political appointees must show their farms before they can be appointed. This "operation show your farms" must be encouraged. 
6. Re-orientation of Ebonyi Youths: Political appointees have a big role to play in enlightenment and re-orientation of the youths of Ebonyi. Apart from encouraging them to access various government programmes aimed at boosting economic recovery, they should be made to know that the tendency to get rich overnight without hard work does not work. Youth must be told to shun cultism, gangsterism, hooliganism, online fraud and other acts of indiscipline and embrace hard work and dignity in labour.

\section{RECOMMENDATIONS FOR POST COVID -19 ECONOMIC ADJUSTMENTS}

It is recommended for every Ebonyi State citizen - rich or poor, old or young, educated or illiterate, between now and the end of Covid - 19, to:

1. Limit spending and encourage savings

2. Live within his/her income

3. Avoid high rate loans from lending institutions and private lenders

4. Pursue vigorous family planning

5. Go back to the farm

6. Redirect greater percentage of his/her income to the welfare of family, particularly, school fees, food and drugs

7. Avoid flamboyant life style

8. Reduce the acquisition and consumption of luxury items

9. Regularly go for medical checks

10. Shun corruption and other acts of indiscipline

11. Be more entrepreneurial innovative

12. Always abide by the rules.

13. Access various government programmes aimed at alleviating the effects of the pandemic.

\section{CONCLUSION}

Covid - 19 may just have come to stay like any other disease in the world. Until a vaccine or drug is quickly found, we have to adjust to accommodate it. No doubt all sectors of world economy have been affected by the pandemic. It is the belief of this paper that if all the postulations made herein are adhered, economic recovery and adjustments after Covid-19 may be much easier. It must be pointed out that all the measures recommended here for a quick economic recovery after the pandemic requires some efforts, not just prayers. Firms that are not registered with the Corporate Affairs Commission (CAC) have to make efforts to do so. People should be encouraged to pay tax, establish farms, in order to make access to government assistance much easier. Political appointees have to embark on enlightenment campaign to let Ebonyi indigenes know the windows opened for them to recover from economic recession and depression after the corona virus disease.

\section{REFERENCES}

[1] Blanke, J. (2020). Economic Impact of Covid- 19: Protecting Africa's Food System From To Fork. African in Focus, June 19.
[2] Trading Economics, (2020). Nigeria - Economic Forecasts 2020-2022 Outlook. tradingeconomics.com

[3] United Nations, (2020). "The Framework for Immediate Socio-Economic Response to The Covi-19 Crisis. www.undp.org.

[4] World Bank, (2020). The Global Economic Outlook During the Covid-19 Pandemic: A Changed World. www.worldbank.org

[5] World Bank, (2020). "Nigeria in Times of Covid-19: Laying Foundation for a Strong Recovery" in World Bank Nigeria Development Update, June ed. 